\title{
Farmers' Perceptions on Climate Variability and Adaptation Strategies to \\ Climate Change in Cinzana, Mali
}

\author{
Touré Halimatou A (Corresponding author) \\ Department of Civil Engineering, \\ KNUST, Kumasi Ghana. \\ Zampaligré Nouhoun \\ Centre International de Recherche , \\ Developpement sur l'Elevage en Zone Sub humide (CIRDES), and Institut de \\ l'Environnement et de Recherches Agricoles (INERA), Bobo Dioulasso, Burkina Faso \\ Traoré Kalifa \\ Rural Economic Institute, \\ Soil-Water-Plant Laboratory, Sotuba. Bamako, Mali \\ Kyei-Baffour N. \\ Department of Agricultural Engineering, \\ KNUST, Kumasi, Ghana.
}

Received: April 18, 2016

Accepted: May 1, 2016

Published: June 8, 2016

doi:10.5296/jas.v4i3.9331

URL: http://dx.doi.org/10.5296/jas.v4i3.9331

\begin{abstract}
Several studies predict that climate change will highly affect the African continent. These changes in climate and climate variability may be challenging issues for future economic development of the continent in general, and particularly in the region of sub Saharan Africa. Offering a case study of Sahelian zone of Mali in the present study aimed to understand farmers' perceptions of climate variability and change and to evaluate adaptation options used by farmers in the Cinzana commune of Mali. One hundred and nineteen farmers were interviewed using a questionnaire designed with six sections. The result showed that all farmers interviewed were aware of climate change and climate variability. The Farmers perceived a decrease in annual rainfall variability and an increase of temperature as main factors of climate change and climate variability. The observed meteorological data, showed a
\end{abstract}


decrease of precipitation distribution during the last 14 years of which was observed by farmers. Several strategies such as selling animals, use of improved crop varieties, new activities (outside agriculture) and credit were the commonly preferred adaptation strategies to deal with climate change and variability. Factors surveyed, age, gender, education, household size, farm size were found to be significantly correlated to self-reported to adaptation.

Keyword: farmers, perception, adaptation, climate change, climate variability, Cinzana commune

\section{Introduction}

Climate change causes extreme weather and unpredictable events which impact and increasingly affect crop growth, availability of soil water, soil erosion, droughts and dry spells, floods, sea level rise with prevalent of pest infestations and diseases (Adejuwon, 2004; Zoellick and Robert, 2009). Many studies have shown that climate change will highly affect the African continent and will be one of the most challenging issues for future economic development, particularly in the sub-Saharan Africa (Roudier et al., 2011). Because most of the population rely on natural resources, they are often practical affected by climate variability and change, especially the poorest (Morton, 2007). Particularly, smallholder farmers in sub- Saharan Africa are strongly impacted (Sivakumar et al., 2005). Local societies already have in-depth knowledge of local climate change and variability as parts of their local ecological knowledge, obtained and transferred through generations (Berke et al., 2000). Several scholars on climate change perception deals with precipitation and temperature in terms of the annual amount, the length and annual distribution of rainfall (Deressa et al., 2009; Fisher et al., 2010). Meteorological data are used to confirm local farmers' assessment of climate change. However, some authors emphasized the need to consider climate in a wider context such as in health or polices (Mubaya et al., 2012; Shackleton and Shackleton, 2012).

According to Parrry et al. (2007), climate change and agriculture are interrelated processes, both of which take place on a global scale. It is predicted that global warming will have important effect on agriculture (McCarthy et al., 2001; Funk et al., 2008). These determine the biosphere's capacity to produce enough food for the human population and domesticated animals. Overall impact of climate change on agriculture will depend on changes in average temperatures, rainfall, and changes in pests and diseases; (Fisher et al., 2002). Studies show that Africa's agriculture will be affected negatively by climate change (McCarthy et al., 2001; Dinar et al., 2008; Pearce et al., 1996). About 25-42 \% of species in Africa could be lost, affecting both non-food and food crops. Habitat change has already been observed in some areas leading to species shifts, changes in plant diversity including plant-based medicine and food (McClean et al., 2005). Eleven per cent of arable land will be affected by climate change in the developing countries, which might lead to a decrease of cereal production in up to 65 countries and about $16 \%$ of agricultural GDP (FAO, 2005).

Climate change will hardly harm the agricultural sector in West Africa if any adaptation actions are not taken (Rosenzweig and Parry, 1994; Adger et al., 2003), but the negative 
impact of climate change can significantly be reduced if appropriate adaptation practices are adopted (Waha et al., 2013). The type of adaptation practices and strategies to be undertaken is to some extent first determined by famers' perceptions of climate change (Roncoli et al., 2001; Thomas et al., 2007).

It is widely acknowledging in the Intergovernmental Panel on Climate Change (IPCC, 2007) that global climate is changing. In the same way, there is general consensus that the Sahel will get hotter as a result of global warming. The temperature in the Sahel will increase by $1.2{ }^{\circ} \mathrm{C}$ in 2030 as compared to current temperatures. (Butt et al., 2006). The Sahel is expected to heat up more than the rest of the globe because in-land areas will become warmer than temperatures over the oceans. In the Sahel, temperatures are already close to the maximum for plant growth, especially at the starting of the season. Experiments with different levels of shading showed that temperature has a pronounced effect on millet production in the Sahel (Vandenbeldt and Williams, 1992).

There is therefore, the need to know farmers perceive climate, changes in climate and the environment (Kemausuor et al., 2011). In fact, perception of farmers of climate variability and how these perceptions determine the choice of coping or adaptation strategies (Vedwan, 2006), have been investigated by previous studies in West African Sahel (Akponikpe et al., 2010; Kyekyeku, 2012; Zampaligré et al., 2013; Sanfo et al., 2014; Traore et al., 2014, Kima et al., 2015). Climate change confirmed by most of the farmers up to $98 \%$ of respondents was dependent on the geographical area and prevailing climate across five 5 countries of West Africa (Akponikpè et al., 2010). In the Sahel, more proportion of farmers perceived the change to have started between 20-30 years ago or more while the majority of them perceived it to be less than 10 years ago in the Guinean areas. Farmers in Burkina Faso understood climate change variability primarily based on weather-crop interactions and on events that are associated with climatic fluctuations. Their perceptions were additionally shaped by the cultural frame. Farmers mentioned more erratic rainfall patterns, decreased rainfall amounts, increased temperatures, winds and radiation. In Mali, small scale rural farmers are depended to agricultural sector which depend on rainfall for crop production. According to Butt et al. (2005), national agricultural production earnings in Mali will likely decrease from US\$ 417 million in 1996 to US\$ 256 million by 2030 because of climate change. Like the other sahelians rural population especially whose livelihoods strongly rely on natural resources are already facing many challenges due to their harsh environment (desertification, recurrent droughts and sometimes floods) and poor socio-economic conditions (Mortimore and Adams, 2001). This study aimed at assessing Cinzana farmers in the Sahel zone in Mali perception on climate change variability and their adaptation practices to overcome or reduce the negative impact of climate change on their farming system as well as their livelihoods.

\section{Material and Methods}

\subsection{Overview of the Study Area}

This research was conducted in the Cinzana commune in the circle of Segou in the Segou Region of south-central Mali. Cinzana is located around latitude 13'15 N, longitude 5'58 W with an altitude of $289 \mathrm{~m}$. The characteristic feature is the alternation of long dry season from 


\section{Macrothink}

Journal of Agricultural Studies

ISSN 2166-0379 2016, Vol. 4, No. 3

November to May and raining season from June to October. The average annual rainfall of the last ten years is 650-750 $\mathrm{mm}$. This amount which is unevenly distributed over the period is insufficient for the needs of crops which largely explains the successive years of crop failure. The average temperature ranged between $28-33{ }^{\circ} \mathrm{C}$ with $39-40{ }^{\circ} \mathrm{C}$ as the highest and lower threshold of $8{ }^{\circ} \mathrm{C}$ to $12{ }^{\circ} \mathrm{C}$. 


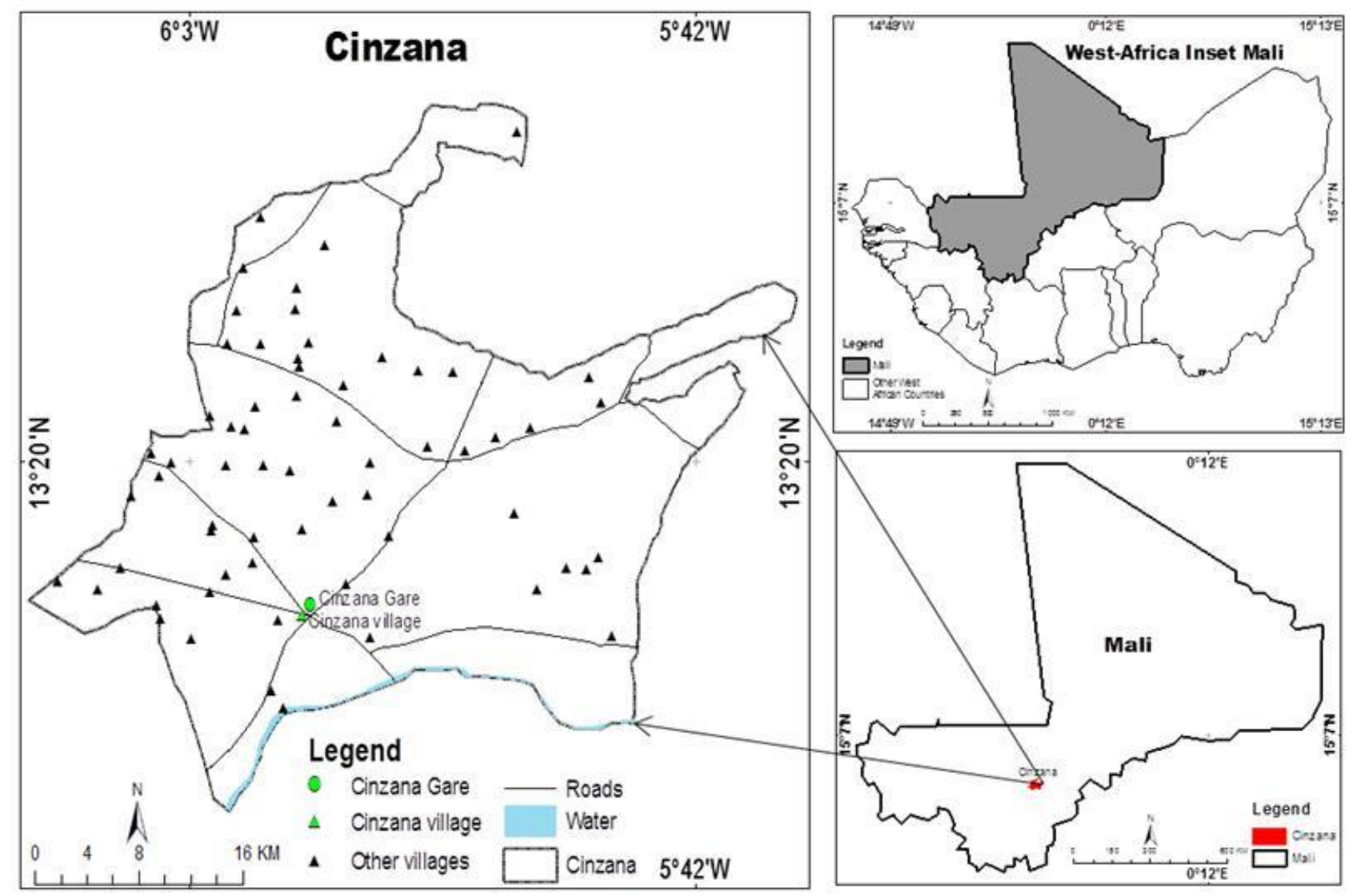

Figure 1. The location of the study area

Cinzana rural town has a population of 37,572 composing of 18,727 (52\%) males and 18,844 $(48 \%)$ females. . The main economic activity of the commune is agriculture and the main crops are millet, sorghum and maize. The produce is primarily intended for home consumption because of poor rainfall, low soil fertility, and high cost of inputs which makes the production expensive . However, some farmers using improved technologies developed by the Institut D'Economie Rurale du Mali are able to generate surpluses that are traded on the weekly market at Cinzana. Farmers grow secondary crops like fonio, groundnuts, bambara groundnut, cowpea and sesame.

A series of on-farm surveys were conducted at Cinzana in 2013. One hundred and nineteen farmers' household including women and youth were randomly selected in the villages and were interviewed using structured questionnaire. The following formula was used to select the number of farmers:

$\mathrm{n}=\mathrm{t}^{2} \times \mathrm{N} / \mathrm{t}^{2}+(2 \mathrm{e})^{2}(\mathrm{~N}-1)$

- $\mathrm{t}$ :Confidence level ( value of the confidence level of $95 \%$ which is 1.96 )

- $\mathrm{N}=$ Size of the population (number of households in this case) 


\section{Ml Macrothink}

Journal of Agricultural Studies

ISSN 2166-0379

2016, Vol. 4, No. 3

- $\mathrm{n}$ : minimum sample size to obtain significant results for an event and obtain significant result for an event and a given level of risk

- $\mathrm{e}=$ level of precision (state to $10 \%$ in this study)

Then the formula will be:

$$
\mathrm{n}=\frac{1.96^{2} N}{1.96^{2}+(2 e)^{2}(N-1)}
$$

The structured questionnaire collected information on farming systems, perception on climate change and concerns for climate change. The questionnaire was designed in English and French but interviews were conducted in the local language, Bambara. The questionnaire was designed under the following 6 sections:

Section A describes the general information related to the farmers which included the socio-economic characteristics of the households and farming activities.

Data collected were age groups, gender, educational level, secondary activity practices, household size, main crop, land holding, average duration of continuous crop farming, fallow use and fallow age.

Section B concerned farm production, which focused on food coverage, food self-sufficiency, crop yield and yield patterns for the last ten years.

Section $\mathbf{C}$ dealt with farmers perceptions on climate change. The data collected were on climate change impact, the different measures taken by farmers against the climate change impact, access to meteorological data and meteorological data type, and the identification of traditional methods for predicting weather.

Section E was on vulnerability and climatic risk management. Data recorded were on mitigation and adaptation strategies, food security and main climate change adaptation strategies.

Interviews were conducted in November 2013. The questionnaire was pretested for its suitability before interviews were conducted. The pretesting include behaviour coding of interviewer/respondent interactions, interviewer debriefings, respondent debriefings and the analysis of item nonresponse rates and response distributions. Precipitation and temperature data were sourced from the Cinzana Meteorological station over the period from 1961 to 2014. The data gave an overview of the trends of precipitation and temperature and the vulnerability of the region to drought.

\subsection{Data Analyses}

Data from the questionnaire were coded and then analysed using the Statistical Package for Social Sciences (SPSS version 20) and MS Excel software. Descriptive statistical tool such as means, standard deviations, frequencies and percentages were used to summarize and categorize the information gathered. Cross tabulation were used to compare group's means. Correlation analysis was used to determine whether household income rather than education 


\section{Macrothink}

Journal of Agricultural Studies

ISSN 2166-0379

2016, Vol. 4, No. 3

level significantly influenced adaptation strategies to climate variability and change. For the climatic variables analysis, the annual rainfall average and index of Nicholson (RI) which is a reduced central variable calculated on annual precipitation to highlight fluctuations in rainfall patterns were calculated. It is the ratio of the difference in inter-annual to average standard deviation of annual precipitation amounts. Nicholson indices play a very important role in determining precipitation fluctuations (wet, normal and dry period). Nicholson et al. (1988) cited by Paturel et al. (1997) have defined an index which is calculated for each year as

$$
R I=\frac{X i-\bar{X}}{\sigma}
$$

Where:

RI: Rainfall Index

Xi: Rainfall in year in millimeters

$\mathrm{X}$ : Average height of average rainfall over the period of study in millimeters

$\sigma=$ standard deviation of the rainfall over the study period.

The Nicholson index determines a reduced central variable (Lamb, 1982) as quoted by (Servat et al., 1998). Inter-annual average of a series is the index zero (0) by the method of Nicholson.

\section{Results and Discussion}

\subsection{Socio-Economic Characteristics of Respondents}

About $92.7 \%$ of famers interviewed in the survey were male headed households and aged between 36 and 55 years. Data showed that about $13.4 \%$ of household heads attended secondary school, $31.8 \%$ attended primary school and $48.7 \%$ were illiterates. The average household size was more than 20 people by $55.6 \%$. Also, $52.1 \%$ of the household heads were polygamous. The most experienced farmer in term of average duration of continuous farming was 50 years. Millet was the main cereal crop grown in the locality and is grown by $63 \%$ of the farmers followed by sorghum $27 \%$ and maize with $8 \%$ (Fig. 2). Farmers found that millet contributed the most to satisfy their subsistence needs and income followed by sorghum and maize. The reasons for high cultivation of millet among farmers is attributed its high productivity, consumer preference and drought tolerance. About $46 \%$ of farmers grew millet because of its high productivity, $16 \%$ grew it because of its consumer preferred traits and $21 \%$ cultivated millet because of its tolerance to drought (Fig. 3) 


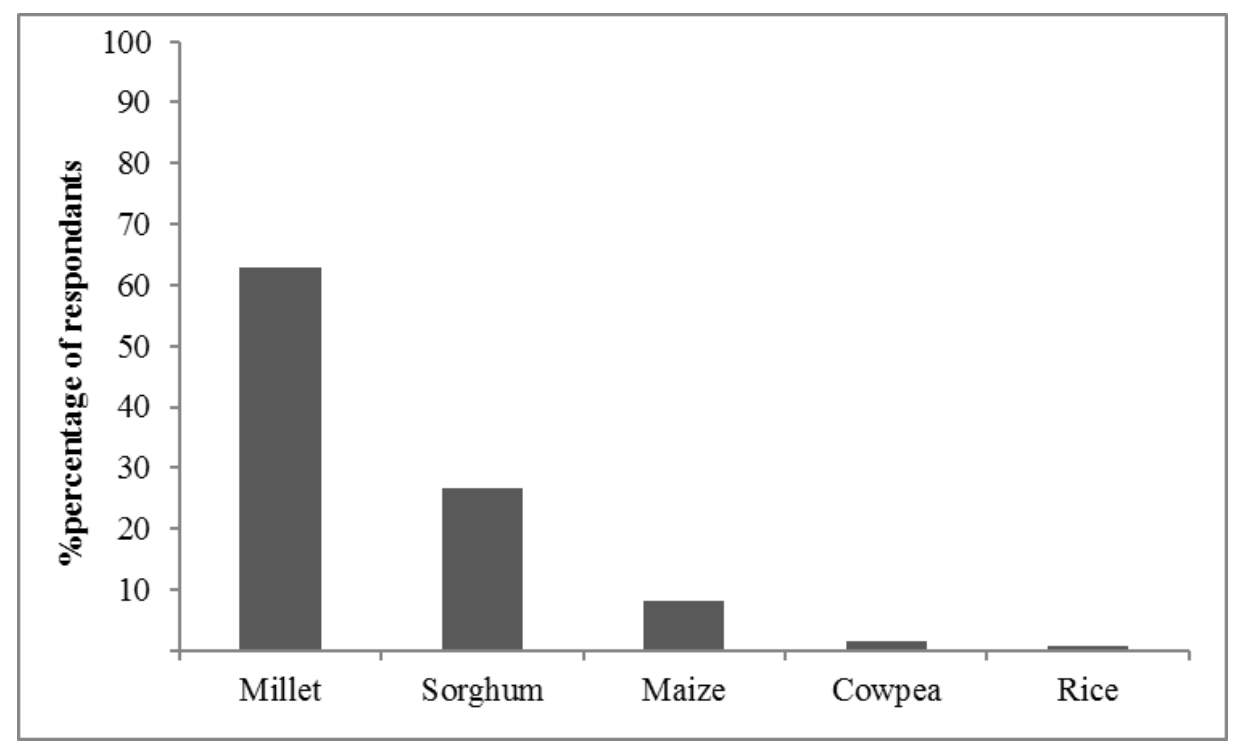

Figure 2. Main crops cultivated by farmers at Cinzana in 2013

The population of Cinzana is dominated by relatively young people of less than 60 years old and male headed households. These male headed households are the active population in the locality. The main socioeconomic factors that impacted on adaptation decisions were level of education, gender and age of the household head, household size and years of farming experience. Effect of age on farmers' adaptation to technology contradicts existing in literature (Teklewold et al., 2006; Glwadys, 2009). In the view of Teklewold et al. (2006) and Glwadys (2009) adaption is mostly influenced by location or technology and specific findings of age are interesting empirical results. This is because the decision to adopt a technology is not easily accepted by older farmers compared to younger farmers.

The average size of a household in this locality was very large (20 persons) compared too many households in other locations in Mali. In Cinzana, female-headed households were non-existence as females are supported by men for subsistence according to their culture. However, women can practice some activities to improve their main source of income. Household size influenced the decision to adapt. Therefore, household size is a proxy to labour availability and may influence adoption of the new technology positively as its availability reduce the labour constraints (Teklewold et al., 2006), However, there is a possibility that households with many family members may distract the labour force to off-farm activities in attempts to earn income to ease the consumption pressure imposed by the large family size (Tizle, 2007).

The gender of household head influenced the decision to adopt the change. Several scholars in Africa have shown that women have access to critical resource (cash, land and labour), which often undermines their ability to carry out intensive labour agriculture innovation (Quisumbing et al., 1995; De Groote and Coulibaly, 1998). According to Nhemachena and Hassan (2007), female-headed households are more likely to take up climate change adaptation methods. A number of studies found that, the possible reason for this observation is that in most local smallholder farming communities in the region, men are more often 


\section{Macrothink}

Journal of Agricultural Studies

ISSN 2166-0379

2016, Vol. 4, No. 3

based in towns and much of the agriculture work is done by women (Nhemachena and Hassan (2007); Quisumbing et al., 1995; De Groote and Coulibaly, 1998).

However, level of education and literacy rate provides information about development at regional and national levels and they reflect people's chances of alternative sources of income and livelihood. The literacy rate among farmers in Cinzana is substantially very low, only $13.4 \%$ of people have attained secondary education. The farmers who attained secondary education level rely firstly on subsistence farming as their main source of income. Education level is often an assumption to increase in the understanding of adoption a new technology (Adesina and Forson 1995; Daberkow and McBride, 2003). This is because education is expected to increase the ability to receive, and understand information relevant to making innovative decision (Wozniak, 1984).

With an average rainfall of $650 \mathrm{~mm}$ in Cinzana, millet is largely cultivated, particularly on marginal lands. These areas are further characterized by variable and a short rainy season, irregular rainfall and a high evaporative demand (high radiation and temperatures). Lastly, the soils are acidic with low mineral fertility (specially low in phosphorous) and organic matter content. For all of these reasons, millet is considered to be the farmers preferred crop in Cinzana because of the low rainfall and adverse soil factors. Experience of farming probably increase the uptake of all adaptation option because of farmers' experiences that make them have better knowledge and information on change in climatic conditions as well as crop and livestock management practices (Hassan and Nhemachena, 2008).

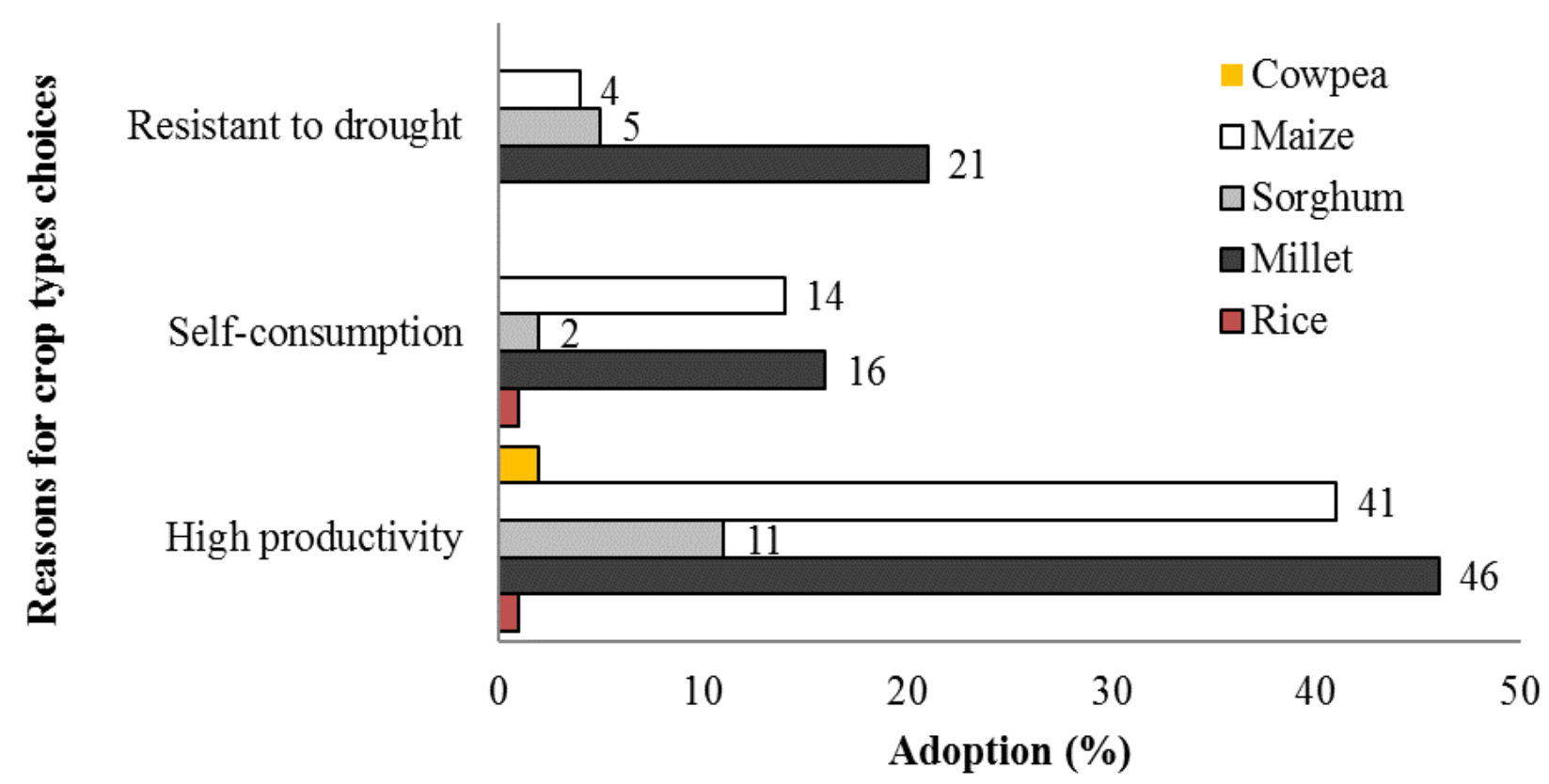

Figure 3. Cinzana farmer's reasons for crop choices 


\section{MInstitute Macrothink}

3.2 Farmers' Perceptions of Climate Change and Variability and its Impacts on Their Farming System

All the respondent in the region believe that the climate is changing and is no longer as it was some years back. Each farmer gave their perception on each of the following factors: length of rainy season, soil fertility, crop yield, vegetation cover, temperature and drought. Figure 4 indicates that $94.1 \%$ of the respondents perceived a decrease in the length of the rainy season. The respondents perceived a decrease in soil fertility as represented by $68.9 \%$ (Fig. 4). Most of the soils in the locality were very poor in fertility. About $27.7 \%$ of the farmers interviewed indicated that the loss of the vegetation cover was due to climate change. Surprisingly, only $15.9 \%$ of the respondents' had perception of climate change indicated a decreased crop yield; $10.9 \%$ of respondents observed drought while $8.4 \%$ found temperature change over the years. The farmers were using local knowledge to predict weather. More than $50 \%$ of the farmers traditionally referred to tree flowering in the region for weather prediction while $38 \%$ use animal migration. Other less important factors are direction of wind (4.2\%) and change in temperature $(1.6 \%)$. Furthermore, the respondents were asked about their perception on climate change and climate variability and their effect on the environment. Most of the farmers $(87 \%)$ indicated that agricultural areas have expanded followed by more vegetable cultivation and lowland cultivation with $69 \%$ (Fig. 5) They also found that forest areas (trees) have reduced by $(65 \%)$ and the savannah ( the grazing area) has also decreased $(61 \%)$. Figure 6 indicates that $94.1 \%$ of the respondents perceived a decrease in the length of the rainy season.

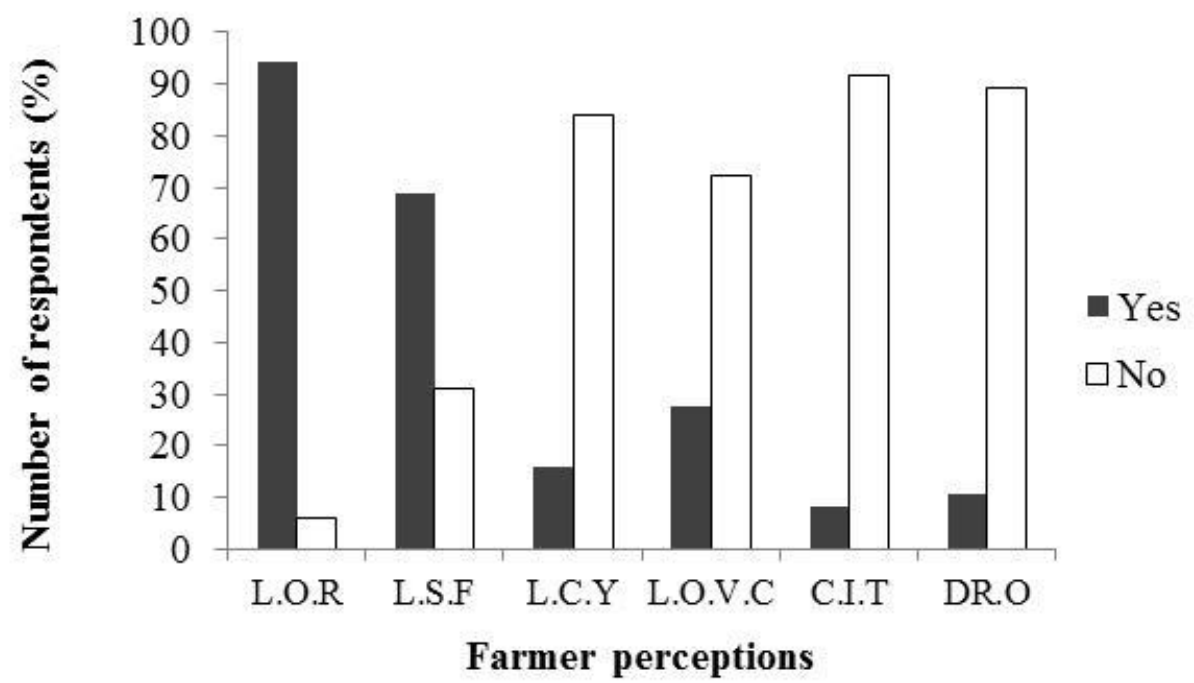

Figure 4. Farmers' perceptions of climate change and variability in Cinzana commune in 2013

NB: L.O.R: length of rainy season, L.S.F: Low soil fertility, L.C.Y: low yield, L.O.V.C: Loss of vegetation cover, C.I.T: Change in temperature and DRO: Drought. 


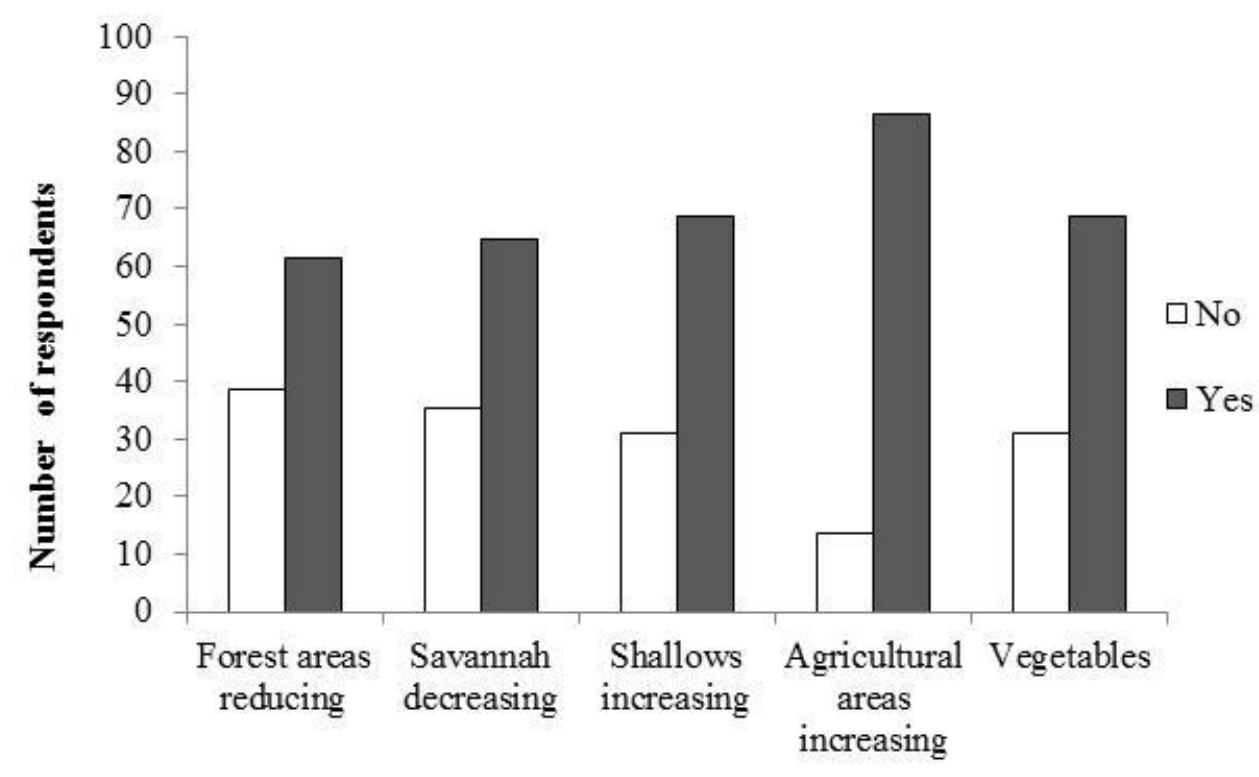

Farmer perceptions

Figure 5. Farmer's perception of climate change and variability in the environment at Cinzana in 2013

Smallholder farmers in Cinzana are aware of climate variability and change, principally through their experiences by appreciating the length of the rainy season, soil fertility, crop yield, vegetation cover, temperature and drought. Some changes were observed on farmers' knowledge as factors used to predict weather. These included change in flowering period for some trees in the region, animal migration especially some birds, wind intensity and direction and high temperatures.. This perception agrees with the general opinion that climate is changing (IPCC, 2007; McCarthy et al., 2008; Orindi and Eriksen, 2005; Lobel et al., 2013; Alexander, 2013). Furthermore, studies on farming perception in semi-arid environment of Africa (Nyanga et al., 2011; Osbahr et al., 2011) and farmer perception on climate variability and change in semi-arid Zimbabwe e (Moyo et al., 2012) showed similar findings.

This study indicated that farmers at Cinzana believe that climate is changing, and it was perceived to affect agricultural productivity negatively. There is, however, divergence of perceptions amongst the farmers, as indicated by the results of what is causing the change in agricultural productivity. Famers reported a number of changes within their location; however, contradictions were apparent among them about the exact nature and the intensity of the changes. This may explain the different perceptions farmers have on effect climate variability and climate change had on agricultural production and productivity. Therefore, climate change and variability is often given as the main reason for crop failure and food shortage (Traore et al., 2014; Mishra et al., 2008; Sultan et al., 2005). 


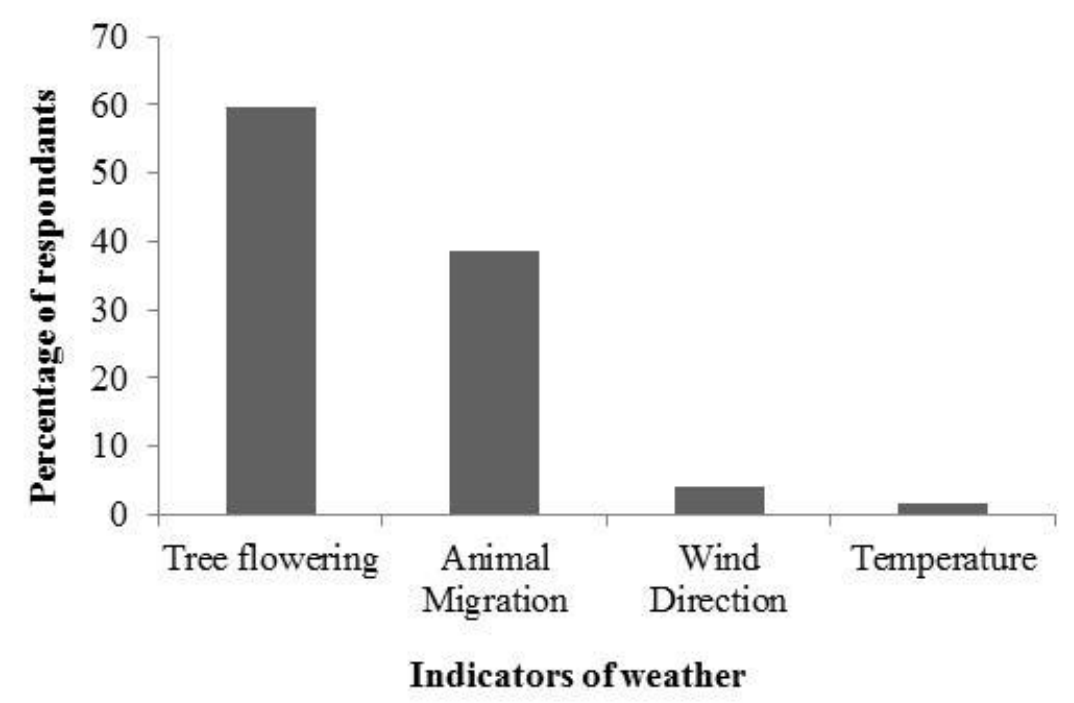

Figure 6. Traditional method to perceived climate change and variability for Cinzana commune farmers

\subsection{Climatological Evidence Compared to Famers'Perceptions}

\subsubsection{Rainfall and Temperature Data}

There were two periods regarding the rain season in the study area (Fig. 7). The dry period from 2000 to 2007 showing rainfall index supported by negative value index of this period, while the wet period from 2008 to 2012 showed a positive rainfall index value. The analysis showed the beginning of the dry period was supported by negative rainfall index for the 2013 year; which is in agreement with farmers' perceptions in this study. Overall there was a decrease of precipitation distribution during the 14 years of observations since 8 out of the 14 years indicated a negative index against $6 / 14$ for the positive index. Rainfall is the most important variable that farmers perceived since it had a clear signal in the record of climate.

The analysis of temperature means during the same period showed a clear increase in temperature from 2000 to 2007 while from 2008 to 2012 it decreased (Fig. 8.). This was not in agreement with farmers in the study area. Few of the respondents perceived that temperature had changed, and could be explained by the fact that in the Sahelian agro ecological zone, farmers focus more on rainfall distribution than temperature. 


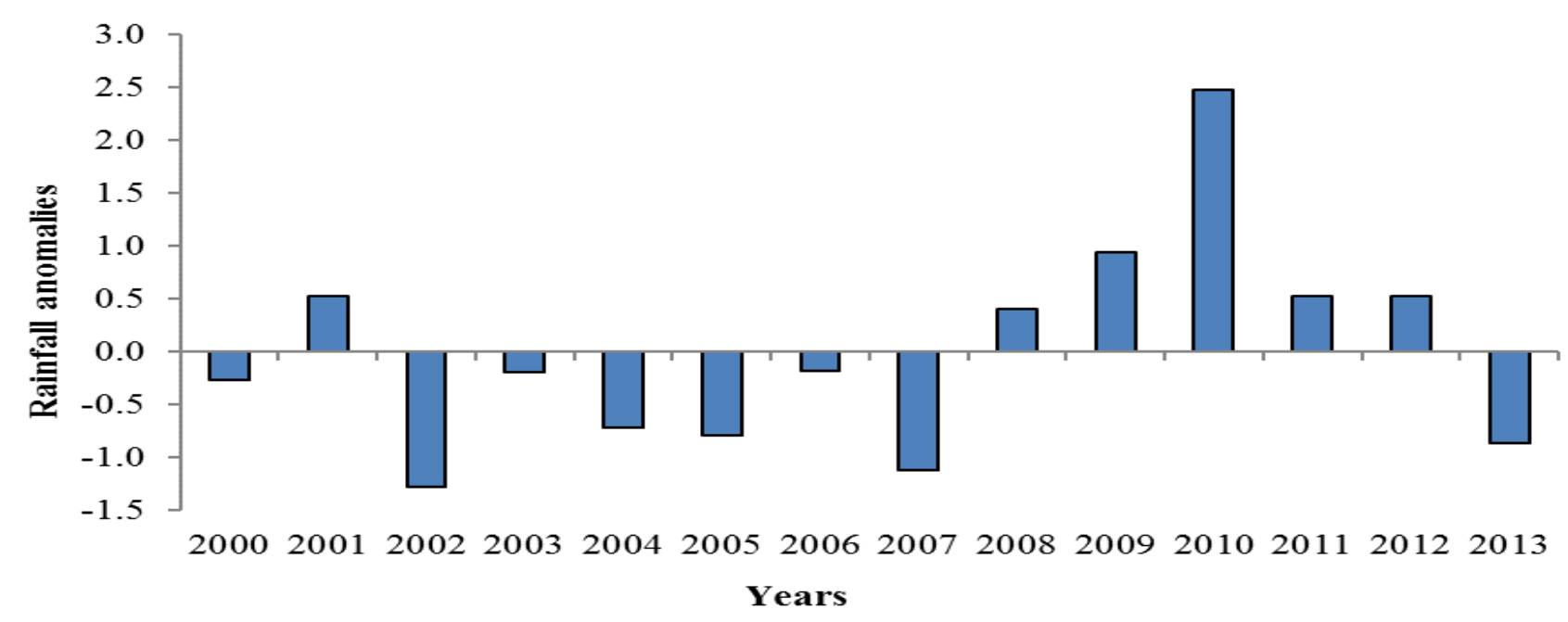

Figure 7. Annual rainfall indexes (mm) from 2000 to 2013 in Cinzana (Data source: Cinzana meteorological Station)

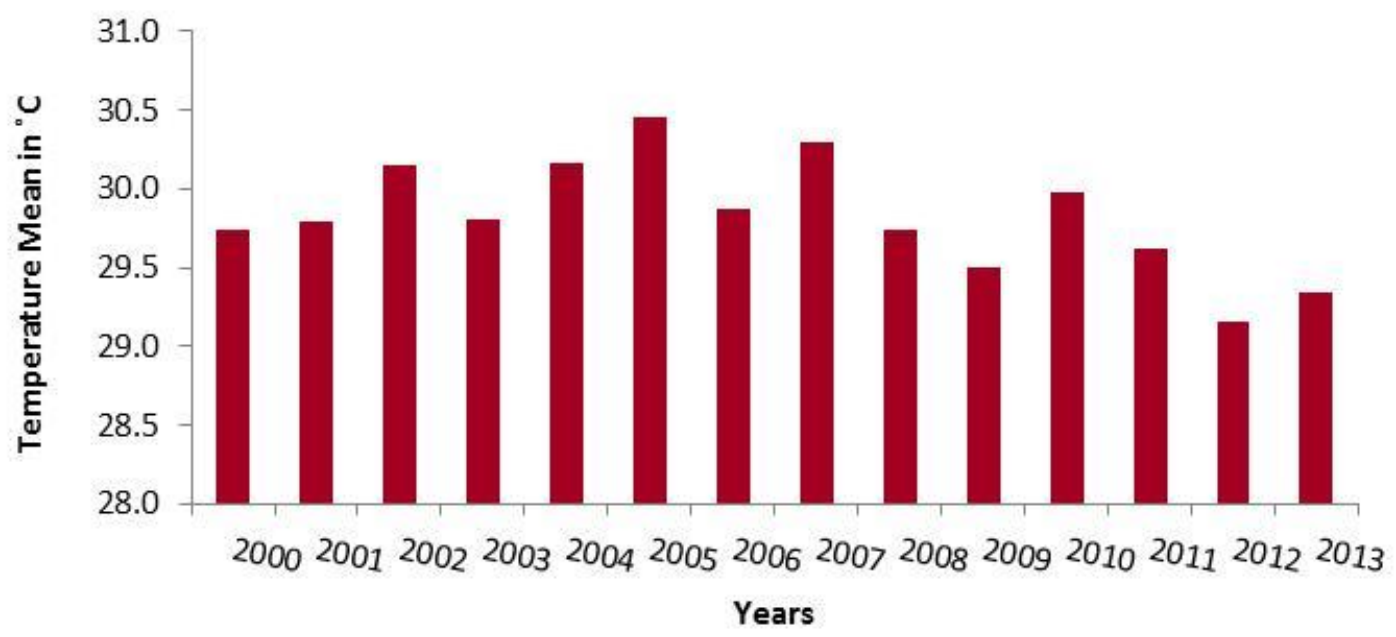

Figure 8. Annual temperature means from 2000 to 2013 (Data source: Cinzana meteorological Station).

The decrease of annual rainfall indicated by farmers was confirmed through an analyses of observed historical data in southern Mali (Mouhamed et al., 2013; Traore et al., 2014), showing an increase in the inter-annual rainfall variability. Furthermore, a study by Cooper et al. (2008) supports the same results for the Sub-Saharan Africa. In several countries, significant results between observed and farmers perception of climate change and variability were found (Apata et al., 2009; Deressa et al., 2009). However, most farmers perceived a continuous decrease of annual rainfall which was not confirmed by the analysis of climate data. No clear change in total precipitation was observed over the last five decades in the Sudanian zone of Mali (Traore et al., 2013). Changes in annual rainfall that farmers think they have been experiencing could be caused by the increase and decrease in the year to year variability of seasonal rainfall (Balme et al., 2006).

However, farmers may be reporting overall decline which could be attributed to temperature increase. For temperature, some farmers' perception of a substantial increase matches the 
empirical observations for the region very well (Hulme et al., 2001). Farmers linked the temperature increase to a change in the number of drought days in the growing season, as these are perceived to be hot. Osbahr et al. (2011) showed that temperature increases led to increased evapotranspiration rates by linking to the faster depletion of soil water. Researchers found the high levels of depletion of soil water resulted from high rates of evapotranspiration normally leading to crop wilting, and causing crop failure, which the farmer may be attributing to a decline in rainfall.

\subsection{Coping and adaptation Mechanisms to Climate Change and Variability}

To cope with the negative impacts of the perceived change in climate patterns on their farming systems, the majority of the farmers in the study areas have adopted some adaptation strategies and coping practices. Among these practices, the most commonly adopted strategies were the use of adapted crop varieties such as drought or pest tolerant crop varieties, early sowing and the use of organic mature as fertiliser. Other practices were the systematic use of chemical fertilizers, change in cropping system, more labour investment and rainwater harvesting. Table 1 indicates that about $75 \%$ of the respondents interviewed used adapted crop varieties that are the most tolerant to drought for the zone while $73.1 \%$ use early crop sowing for the different crop varieties to optimise the available moisture in the soil. Concerning organic manure use as an adaptation practice, $32.8 \%$ of the respondents used this to reduce the impact of climate change and climate variability. Other strategies mentioned by respondents were the use of chemical fertilizer (28.6\%), cropping system (13.4\%) and rainwater harvesting $(1.7 \%)$.

Table 1. Coping strategies to climate change and variability of farmers in Cinzana commune in 2013

\begin{tabular}{lc}
\hline Adopted practices & Farmer's response (\%) \\
\hline Adaptation practices & Yes \\
\hline Variety adapted & 75.6 \\
Early sowing & 73.1 \\
Organic manure use & 32.8 \\
Mineral fertilizer use & 28.6 \\
Cropping system changes & 13.4 \\
Rainwater harvesting & 1.7 \\
\hline Coping practices & Yes \\
\hline Cropping system & 65.5 \\
Organic manure & 63.5 \\
Use of adapted crops & 41.2 \\
Rainwater harvesting & 3.4 \\
Livestock selling & 0.8 \\
Buying supplies & 0.8 \\
\hline
\end{tabular}

Results of adaptation strategies to climatic stressors undertaken by households are given in Figure 9. The major adaptation mechanisms include selling livestock especially small 
ruminants and poultry (42\%), utilization of improved crop seeds and seeking other activities outside agriculture $(11.7 \%)$, getting credit $(10 \%)$ and use of manure $(8.4 \%)$.

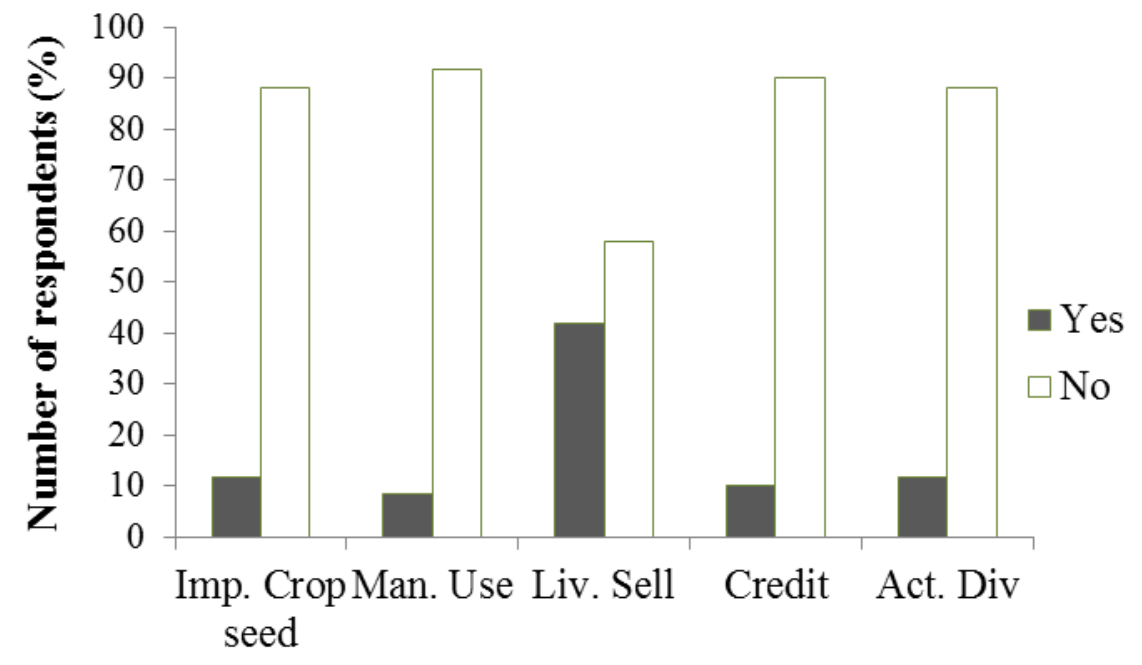

\section{Adaptation Strategies}

Figure 9. Farmer's adaptation strategies to climate change and variability in Cinzana commune, 2013.

NB: Imp.crop seed= improve crop seed, Man. Use= manure used, Liv. Sell= livestock selling, Act. Div= activities diversification

Descriptive statistics results have shown that farmers in the study area have adapted to the effect of climate change through a number of mechanisms. Households have multiple strategies related to agriculture and engaged in off-farm activities to complement their household incomes and food in case of adverse conditions in agriculture. The majority of respondents reported that they have used more than one type of adaptation and coping strategies. This decision implies that a single strategies is inadequate in adapting to the impact of climate change as a combination of several strategies is likely to be more effective than a single strategy. The major coping mechanisms to climate change undertaken by households were adapted crop seed varieties; which is different from the studies on coping mechanisms by Fana and Asnake (2012) in Ethiopia, Quay (2008), Kyekyeku (2012) in Ghana, and Bardege et al. (2013) in where? who obtained various diversified coping strategies in response to climate change, which most of them related to the coping mechanism found in the study.

The findings reveal that households in Cinzana commune had several adaptation strategies in response to the effect of climate change and variability. The major strategies included use of adapted varieties, use of organic matter and selling of animals. This implies that climate variability and change is not a new phenomenon to the Cinzana commune. Those strategies are not strange but have a close relationship to those carried out elsewhere. However, a study done in 11 African countries by Nhemachena and Rashid (2008) found that diversified adaptation mechanisms to climate change such as diversifying production, using different improved varieties, changing planting dates, increased irrigation, use of insurance, water conservation, prayers, soil conservation were used., The adaptation strategies adopted in 
different regions or countries depend on their level of economic development, technology, financial capacity, institutional support and traditions. Therefore, each region tends to have most similar adaptation strategies adopted.

\subsection{Correlation Estimation of Some Factors Influencing the Farmers'Adaptation Strategies to Climate Change Effects}

To diagnose correlation, the contingency coefficient test was applied and omits independent variables that are strongly correlated and dependent on each other (Table 2.) were used. The study observed multi-correlation between age and farming experience, sex and farming experience, household size and number of farms, secondary activities and farming experience, sex and education, education and household size, sex and number of farms.

Table 2. Correlation of factors studied on adaptation mechanisms in Cinzana commune

\begin{tabular}{lllllllll}
\hline & Ag & Gen & Edu & Hldsize & Adpstra & Farsize & Farexp & Income \\
\hline Age & 1 & & & & & & & \\
Gender & -0.019 & 1 & & & & & & \\
Edu & -0.127 & $-0.177^{*}$ & 1 & & & & & \\
HldSiz & $0.169^{*}$ & -0.122 & $.164^{*}$ & 1 & & & & \\
Adstra & 0.057 & 0.099 & -0.005 & 0.073 & 1 & & & \\
Landsize & 0.132 & $-0.184^{*}$ & 0.110 & $0.355^{* *}$ & 0.013 & 1 & & \\
Farexp & $0.208^{* *}$ & $-0.228^{* *}$ & 0.089 & $0.255^{* *}$ & -0.038 & $0.262^{* *}$ & 1 & \\
Income & 0.004 & -0.161 & 0.068 & 0.112 & 0.170 & -0.057 & -0.050 & 1 \\
\hline
\end{tabular}

* Correlation is significant at 0.05 level

** Corelation is significant at 0.01 level

NB: Ag= age, Gen: gender, Edu= education, Hldize $=$ household size, Adpstra $=$ adaptation strategies, Farsize $=$ farm size, Farexp: farming experience

The results of correlation (Table 2.) indicated a positive correlation $(0.01 \%)$ between age and farming experience. This means that farming experience significantly increase with increase in the number of years of the respondent in farming. Experienced farmers see the need to adapt to climate variability and change effects. Furthermore, these older farmers may be more interested in the following traditional methods familiar to them rather than adopting modern farming techniques. Acquah (2011) and Quayum et al. (2012) found similar results but negative significance. Their findings may be because young adults have more motivation to act on perceived changes in order to cope with it. The ability to adapt depends on individual's motivation to act (Bandura, 1997). Therefore, young adults are able and have energy to get jobs outside agriculture and can also diversify agricultural production which can help them get more income to adopt other adaptation.

The influence of farmers' gender was negatively correlated to the educational level, the number of farms and highly correlated to the farming experience negatively. This influence of gender is because the males were more likely to adapt than their female counterparts since in 
many African traditions the females have less access to land and other socio-economic resources constraining the adaptive capacity of females to adapt to climate change and variability. It was reported by International Food Policy Research Institute (IFPRI, 2001) and Meinzen-Dich et al. (2010) on gender studies that unequal distribution of assets between males and females in rural households was in favour of males. The results from this study agrees with those results by Tenge and Hella (2004) and Nabikolo et al. (2012).

The study also showed a high correlation between the household size and the number of farms and farming experiences. Households with high number of people have more land and more experiences in farming. They are more likely to adapt than their counterparts with small land because those farmers may open up large gardens and plant more crops. People who own more land may rent out some of their land in order to generate more income for the household and be able to adapt more appropriately than those who have less land (Nabikolo et al. (2012). Advancing Capacity to Support Climate Change Adaptation (ACCCA, 2010) reported that large farm sizes positively influences adaptation strategies such as the use of growing trees and improved varieties of crops and livestock.

\subsection{Conclusion}

Farmers in Cinzana commune are conscious and aware of climate change and climate variability, and saw it as a real risk to their livelihood. Various adaptation strategies were used by the farmers in response to climate change through the expansion of their farms, which subsequently result in environmental degradation. Farmers' perceptions of climatic variability are in line with climatic data records. Indeed, farmers in Cinzana are able to recognize reduction in rainfall. The study found that use of improved crop varieties was the major adoption strategy among farmers' adaptation strategies in Cinzana because yield can be increase through improved crop management. Gender, size of land and age of household head are the significant determinants of adaption strategies. Those factors can be identified as influential characteristics of farmers who adopt coping strategies to climate change and variability effects. This study represents a preliminary venture into understanding farmer behaviour and perceptions related to adaptation for global climate change variability. The findings of this study will be helpful for policy makers both in Cinzana commune and other regions of Mali in their interventions and actions to facilitate a shift to sustainable adaptation strategies.

\section{Acknowledgments}

The authors are grateful to the participant farmers from the study area for their kind assistance regarding data collection of this study. The paper is based on the first author's Ph.D. thesis submitted to the Kwame University Nkrumah of Science and Technology (KNUST) Kumasi, Ghana. The Ph.D. programme was sponsored by the West African Science Service Centre on Climate Change and Adapted Land Use (WASCAL).

\section{References}

ACCCA (Advancing Capacity to Support Climate Change Adaptation). (2010). Improving Decision Making Capacity Of Small Holder Farmers In Response To Climate Risk 
Adaptation In Three Drought Prone Districts Of Tigray, Northern Ethiopia, Project No. 093.

Acquah, H. D. (2011). Farmers' Perception and Adaptation to Climate Change Effects: A Willingness to Pay. J. Sustain. Dev. Afr., 13, 150-161

Adejuwon, S. A. (2004). Impacts of Climate Variability and Climate Change on Crop Yield in Nigeria. Paper presented at the Stakeholders' Workshop on Assessment of Impacts and Adaptation to Climate Change (AIACC), Conference centre, Obafemi Awolowo University, Ile-Ife, 271-279.

Adesina, A. A., \& Forson, J. B. (1995). Farmers' Perceptions and Adoption of New Agricultural Technology: Evidence from Analysis in Burkina Faso and Guinea, West Africa. Agricultural Economics, 13, 1-9.

Adger, W. N., Huq, S., Brown, K., Conway, D., \& Hulme, M. (2003). Adaptation to Climate Change in the Developing World. Progress in Development Studies, 3(3), 179-195.

Akponikpè, P. B. I., Peter, J., \& Agbossou, E. K. (2010). Farmers' Perception of Climate Change and Adaptation Strategies in Sub-Saharan West-Africa. 2nd International Conference: Climate, Sustainability and Development in Semi-Arid Regions, Fortaleza - Ceará, Brazil.

Alexander, H. (2013). Asian Scientists: Mekong Region Facing Six Degrees Warming, Climate Extremes, USAID, New York.

Apata, T. G., Samuel, K., \& Adeola, A. (2009). Analysis of Climate Change Perception and Adaptation Among Arable Food Crop Farmers in South Western Nigeria, Contributed Paper Prepared for Presentation at the International Association of Agricultural Economists, Beijing, China, August 16.

Balme, M., Vischel, T., Lebel, T., Peugeot, C., \& Galle, S. (2006). Assessing the Water Balance in the Sahel: Impact of Small Scale Rainfall Variability on Runoff: Part 1: Rainfall Variability Analysis. Journal of Hydrology, 331(1-2), 336-348.

Bandura, A. (1977). Self-Efficacy Towards a Unifying Theory of Behavioral Change. Psychol Rev, 191-215.

Bardege, B., Neufeldt, H., Mowo, J., Abdelkadir, A., Muriuki, J., Delle, G., Tewodros, A.,Barry, S., Burton I., Richard, J. Klein, T., \& Wandel. (2013). An Atomy of Adaptation to Climate Change and Vulnerability, Springs

Berke F., Colding, J., \& Folke, C. (2000). Rediscovery of Traditional Ecological Knowledge as Adaptive Management. Ecological Applications, 10, 1251-1262. http://dx.doi. org/10.1890/1051-0761 (2000)010[1251: ROTEKA] 2.0.CO.2

Butt, T. A., Mccarl B., A., Angerer J., Dyke, P. T., \& Stuth, J. W. (2005). The Economic and Food Security Implications of Climate Change In Mali. Climatic Change, 68, 355-378.

Butt, T. A., \& Mccarl, K. (2006). Policies for Reducing Agricultural Sector Vulnerability to Climate ChangeiIn Mali, Climate Policy, 5, 583-598. 
Cooper, P. J. M., Dimes, J., Rao, K. P. C., Shapiro, B., Shiferaw, B., \& Twomlow, S. (2008). Coping Better with Current Climatic Variability in the Rain-Fed Farming Systems of Sub-Saharan Africa: An Essential First Step in Adapting to Future Climate Change? Agriculture, Ecosystems and Environment, 126, 24-35.

Daberkow, S. G., \& Mcbride, W. D. (2003). Farm and Operator Characteristics Affecting the Awareness and Adoption of Precision Agriculture Technologies in The U.S. Precision Agriculture, 4, 163-177.

De Groote, H., \& Coulibaly, N. (1998). Gender and Generation: An Intra-Household Analysis on Access to Resources in Southern Mali, African Crop Science Journal, 6(1), 79-95.

Deressa, T. T., R. M. Hassan, C. Ringler, Alemu, T. \& Yesuf, M. (2009). Determinants of Farmers' Choice of Adaptation Methods to Climate Change in the Nile Basin of Ethiopia. Global Environmental Change, 19, 248-255.

http://dx.doi.org/10.1016/j.gloenvcha.2009.01.002

Meinzen-Dich R., Quisumbing, B. J., Biermay, J. P., Wilde, V., Noordeloos, M., Ragasa, C., \& Beintema, N. (2010). Engendering Agricultural Research, Global Forum on Agricultural Research, Rome, Italy.

Dinar A, Hassan R, Mendelsohn R. \& Benhin J. (2008). Climate Change and Agriculture in Africa: Impact Assessment and Adaptation Strategies. Earthscan, London. 100-106

Fana, G. \& Asnake, K. (2012). Traditional Coping Mechanisms for Climate Change of Pastoralists in South Omo, Ethiopia, Adis Ababa University, Ethiopia

FAO. (2005). Impact of Climate Change, Pests and Diseases on Food Security and Poverty Reduction. Special Event Background Document for the 31st Session of the Committee on World Food Security. FAO Publication, Rome. 1-10.

Fisher G., Shah M. \& Van Velthuizen H. (2002). Climate Change and Agricultural Vulnerability. International Institute for Applied Systems Analysis. Laxenburg, Austria.

Fisher, M., Chaudhury, M., \& Mccusker, B. (2010). Do Forests Help Rural Households Adapt to Climate Variability? Evidence from Southern Malawi. World Development 38, 1241-1250.

Funk, C, Dettinger, M. D., Michaelsen, J. C., Verdin ,J. P, Brown, M. E., Barlow, M. \& Hoell A. (2008). Warming of the Indian Ocean Threatens Eastern and Southern African Food Security but Could Be Mitigated by Agricultural Development. Proceedings of the National Academy of Sciences, 105(32), 11081-11086.

Glwadys A.G. (2009). Understanding Farmers' Perceptions znd Adaptations to Climate Change and Variability the Case of the Limpopo Basin, South Africa. Environment and Production Technology Division. IFPRI Discussion Paper 00849. 52 P 19.I

Hassan, R., \& Nkemechena, C. (2008).Determinants of African farmers' strategies for 


\section{Mll Macrothink}

Journal of Agricultural Studies

ISSN 2166-0379

2016, Vol. 4, No. 3

adapting to climate changes: multinomial choice analysis. AFJARE, 2(1), 85-104

Hulme, M., Doherty, R., Ngara, T., New, M., \& Lister, D. (2001). African Climate Change: 1900-2100. Climate Research, 17(2), 145-168.

IFPRI (International Food Policy Research Institute). (2001). Empowering Women to Achieve Food Security, Washington, DC

IPCC. (2007). "Summary for Policy Makers", In M. Parry, Ocanziani, \& P. Vander Linden (Eds) Climate Change 2007: Impacts Adaption and Vulnerability Contribution of Working Group II for the Fourth Assessment Report of the Intergovernmental Panel on Climate Change, Cambridge University Press.

Kemausuor F., Dwamena E., Bart-Plange A., \& Kyei-Baffour N. (2011). Farmers' Perception of Climate Change in the Ejura-Sekyedumase District of Ghana. ARPN Journal of Agricultural and Biological Science, 6, 10.

Kima, S. A., Okhimamhe, A. A; Kiema, A. Zampaligré, N., \& Sule, I., 2015. Adapting to the impacts of climate change in the sub-humid zone of Burkina Faso, West Africa, perception of agro-pastoralists. Pastoralism: Research, Policy and Practice http://dx.doi.org/10.1186/s13570-015-0034-9

Kyekyeku, N.F. (2012). Climate Change Vulnerability \& Coping Mechanisms Among Farming Communities in Ghana, Khansas State University, Manhattan, Kansas.

Lobel, D. B., Graeme, L. H., Greg, M., Messina, C., Michael, J. R., \& Wolfram, S. (2013). The Critical Role of Extreme Heat for Maize Production in the United States, New York

Mishra, A., Hansen, J. W., Dingkuhn, M., Baron, C., Traoré, S. B., Ndiaye, O., \& Ward, M. N. (2008). Sorghum yield prediction from seasonal rainfall forecasts in Burkina Faso. Agricultural and Forest Meteorology, 148(11), 1798-1814.

McCarthy, J, Canziani O. F., Leary, N. A., Dokken, D. J., \& White, C. (2001). Climate Change 2001: Impacts, Adaptation, and Vulnerability. Contribution of Working Group II to the Third Assessment Report of the Intergovernmental Panel on Climate Change. Cambridge University Press, Cambridge.

Mccarthy, Canzian, O. F., Leary, N., Dokken, D., \& White, K. S. (2008). Climate Change 2001: Impacts, Adaptation and Vulnerability, Contribution of Working Group II to the Forth Assessment Report of the Inter-Governmental Panel of Climate Change, Cambridge University Press, UK and New York

McClean, C. J., Lovett, J. C., Küper, W., Hannah, L., Sommer, J. H., Barthlott, W., Termansen, M., Smith, G. F., Tokumine, S., \& Taplin, J. (2005). African Plant Diversity and Climate Change. Annals of the Missouri Botanical Garden, 92(2), 139-152.

Mortimore, M. J., \& Adams, W. M. (2001). Farmer Adaptation, Change and 'Crisis' in the Sahel. Global Environmental Change, 11(1), 49-57.

Morton, J. F. (2007). The Impact of Climate Change on Smallholder and Subsistence 
Agriculture. Proceedings of the National Academy of Sciences 104, 19680-19685. http://dx.doi.org/10.1073/pnas.0701855104.

Mouhamed Ly, Traore S. B., Agali A., \& Sarr, B. (2013). Evolution of Some Observed Climate Extremes in the West African Sahel. Journal Weather and Climate Extremes1, $19-25$

Moyo M., Mvumi B.M., Kunzekweguta M., Mazvimavi K., Craufurd P. and Dorward P. (2012). Farmer Perceptions on Climate Change and Variability in Semi-Arid Zimbabwe in Relation to Climatology Evidence. African Crop Science Journal, 20, Issue Supplement S2, 317 - 335 ISSN 1021-9730/2012.

Mubaya, C. P. Njukib J., Mutsvangwa E. P., Mugabe F. T., \& Nanja D. (2012). Climate Variability and Change or Multiple Stressors? Farmer Perceptions Regarding Threats to Livelihoods in Zimbabwe and Zambia. Journal of Environmental Management, 102, 9-17.

Nabikolo, D., Bashaasha, B., Mangheni, M.N., \& Majaliwa, J. G.M. (2012). Determinants of Climate Change Adaptation Among Male and Female Headed Farm Households in Eastern Uganda, African Crop Science Journal, 20(2), 204-212.

Nhemachena, C., \& Hassan, R. (2007). Micro-Level Analysis of Farmers' Adaptation to Climate Change in Southern Africa, IFPRI Discussion Paper No. 714 (Washington, DC: International Food Policy Research Institute, 2007

Nicholson, S.E., Kim, J. \& Hoopingamer, J. (1988). Atlas of African Rainfall and its Interannual Variability. Department of Meteorology, Florida State University, Tallahassee.

Nyanga, P.H., Johnsen, F. H., Aune, J. B., \& Kalinda, T. H. (2011). Smallholder Farmers' Perceptions of Climate Change and Conservation Agriculture: Evidence from Zambia. Journal of Sustainable Development, 4(4), 73-85

Orindi, V. \& Eriksen, S. (2005). Main Stream Adaption to Climate Change in Development Process in Uganda: Nairobi: African Centre for Technology Studies (ACTS).

Osbahr, H., Dorward, P., Stern, R. \& Cooper, S. (2011). Supporting Agricultural Innovation in Uganda to Climate Risk: Linking Climate Change and Variability with Farmer Perceptions. Experimental Agriculture, 47(2), 293-316.

Parry, M. L., Canziani, O. F., Palutikof, J. P, Van Der Linden P. J., \& Hanson C. E. (2007). Climate Change 2007: Impacts, Adaptation and Vulnerability. Contribution of Working Group II to the Third Assessment Report of the Intergovernmental Panel on Climate Change Cambridge University Press, Cambridge, United Kingdom.

Paturel J. E., Servat E., Kouamé B., Lubès H., Ouedraogo M., \& Masson J. M. (1997). Climatic variability in humid Africa along the gulf of Guinea. Part II: an integrated regional approach. Journal Hydrol, 191, 16-36.

http://dx.doi.org/10.1016/S0022-1694(96)03069-7. 


\section{Ml Macrothink}

Journal of Agricultural Studies ISSN 2166-0379 2016, Vol. 4, No. 3

Pearce, D., Cline, W., Achanta A, Fankhauser, S., Pachauri, R., To,1 R., \& Velling,a P., (1996). The Social Costs of Climate Change: Greenhouse Damage and Benefits of Control. In: Bruce J, Lee H, Haites E., Eds., Climate Change 1995: Economic and Social Dimensions of Climate Change. Cambridge University Press, Cambridge.

Quay, W. (2008). Coping Mechanisms to Climate Variability in Ghana, African Journal of Agricultural Research, 3(5), 334-341 May, 2008.

Quayum, M.A \& Ali, A.M. (2012). Adoption and Diffusion of Power Tiller in Bangladesh. Bangladesh J. Agric. Res. 2012, 37, 307-325.

Quisumbing, A., Haddad, L., \& Peña, C. (1995). Gender and Poverty: New Evidence from 10 Developing Countries. FCND Discussion Paper No. 9, International Food Policy Research Institute, Washington, D.C.

Roncoli, C., Ingram, K., \& Kirshen, P. (2001). The Costs and Risks of Coping with Drought: Livelihood Impacts and Farmers ${ }^{1}$ Responses in Burkina Faso. Climate Research, 19(2), 119-132.

Rosenzweig, C., \& Parry, M. L. (1994). Potential Impact of Climate-Change on World Food Supply. Nature, 367, 133-138.

Roudier, P., Sultan, B., Quirion, P., \& Berg, A. (2011). The impact of future climate change on West African crop yields: What does the recent literature say? Global Environmental Change, 21(3), 1073 - 1083. ISSN 09593780

Sanfo, S., Lamber, J. P. A., MUELLER, M., \& FONTA, W. (2014). Farmers’' Perceptions of Climate Change and Climate Variability Versus Climatic Evidence in Burkina Faso, West Africa. Conference: Climate Change in Africa. Negotiations, Translations, and Socio-Political Implications. 10th - 12th September 2014, Center for Development Research (ZEF), Bonn, Germany, at Bonn, Germany.

Shackleton, S. E., \& C. M. Shackleton. (2012). Linking Poverty, HIV/AIDS and Climate Change to Human and Ecosystem Vulnerability in Southern Africa: Consequences for Livelihoods and Sustainable Ecosystem Management. International Journal of Sustainable Development and World Ecology 19, 275-286. http://dx.doi.org/10.1080/13504509.20-11.641039.

Sivakumar, M.V.K., Das, H.P. \& Brunini, O. (2005). Impacts of Present and Future Climate Variability and Change On Agriculture and Forestry in The Arid and Semi-Arid Tropics Climatic Change, 70, 31-72.

Sultan, B., Baron, C., Dingkuhn, M., Sarr, B. \& Janicot, S. (2005). Agricultural impacts of large-scale variability of the West African monsoon. Agricultural and Forest Meteorology, 128(1-2), 93-110.

Teklewold, H., Dadi L., Yami A., \& Dana N. (2006). Determinants of Adoption of Poultry Technology: A Double hurdle Approach. Livestock Research for Rural Development, 18(3). http://www.lrrd.org/lrrd18/3/tekl18040.htm. 


\section{Macrothink}

Tenge, J. D. G., \& Hella, J. P. (2004). Social and Economic Factors Affecting The Adoption of Soil and Water Conservation in West Usambara Highlands, Tanzania, Land Degradation and Development, 15, 99-114

Thomas, D. G., Twyman, C., Osbahr, H., \& Hewitson, B. (2007). Adaptation to Climate Change and Variability: Farmer Responses to Intra-Seasonal Precipitation Trends in South Africa. Climatic Change, 83(3), 301-322.

Tizle, C.Y. (2007). The Dynamics of Soil Degradation and Incentives for Optimal Management in the Central Highlands of Ethiopia. Ph.d Thesis. Faculty of Natural and Agricultural Sciences, University of Pretoria; Pretoria, South Africa.

Traore Bouba. (2014). Thesis on Climate change, climate variability and adaptation options in smallholder cropping systems of the Sudano - Sahel region in West Africa C.T. de Wit Graduate School of Production, Ecology and Resource Conservation, 173

Traore, B., Vanwijk, M. T., Descheemaeker, K., Corbeels, M., Rufino, M. C., \& Giller, K.E., 2014 Farmer's Perceptions on Climate Change and on Agricultural Adaptation Strategies in Southern Mali. Under Review in Experimental Agriculture

Traore, B., Corbeels, M., Van Wijk, M.T., Rufino, M. C., \& Giller, K. E. (2013). Effects of Climate Variability and Climate Change on Crop Production in Southern Mali. European Journal of Agronomy, 49: 115- 125.

Traore S. B., Agali A., Muller, B., Kouressy, M., Somé, L., Sultan B., Oettli P., Ambroise C., Laopé S., Sangaré S., Vaksmann M., Diop M., Dingkhun M. \& Christian B. (2010). Characterizing and Modelling the Diversity of Cropping Situations under Climatic Constraints in West Africa. Atmospheric Science Letters. http://dx.doi.org/ 10.1002/Asl.295.

Vandenbeldt, R.J. \& Williams J.H. (1992). The Effect of Soil Surface Temperatures on the Growth of Millet in Relation to the Effect of Faidherbia Albida Trees. Agricultural and Forestmeteorology, 60, 93-100.

Vedwan, N. (2006). Culture, Climate \& The Environment: Local Knowledge and Perception of Climate Change Among Apple Growers in Northwestern India. Journal of Ecological Anthropology, 10(1): 4-18.

Waha, K., Müller, C., Bondeau, A., Dietrich, J.P., Kurukulasuriya, P., Heinke, J. \& Lotze-Campen, H. (2013). Adaptation to Climate Change Through the Choice of Cropping System and Sowing Date in Sub-Saharan Africa. Global Environmental Change, 23(1), 130-143.

Wozniak, G. D. (1984). The Adoption of Interrelated Innovations: A Human Capital Approach. Review of Economics and Statistics 66 (LXVI): 70-79.

Zampaligré, N., Dossa, H.L.G. \& Schlecht, E., (2013). Climate change and variability: Perception and adaptation strategies of pastoralists and agro-pastoralists across different zones of Burkina Faso. Regional Environmental Change, 14, 769-783. 
Zoellick, S., \& Robert, B. A. (2009). Climate Smart Future. The Nation Newspapers. Vintage Press Limited, Lagos, Nigeria, 18.

\section{Copyright Disclaimer}

Copyright for this article is retained by the author(s), with first publication rights granted to the journal.

This is an open-access article distributed under the terms and conditions of the Creative Commons Attribution license (http://creativecommons.org/licenses/by/3.0/). 